
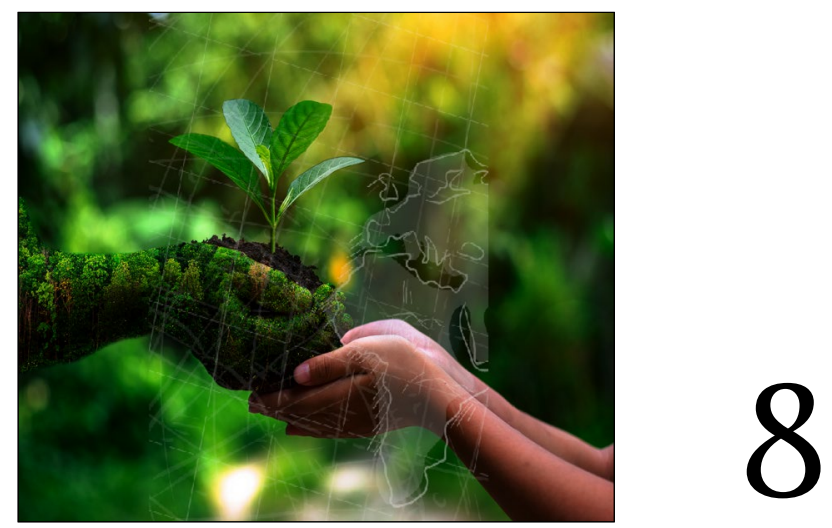

\title{
INCLUSIVE GOVERNANCE FOR SUSTAINABLE DEVELOPMENT IN AFRICA
}

\author{
Mark Swilling
}

\section{Introduction}

Since the onset of the global economic crisis in 2007/2008, two key trends converged in ways that require a new discussion about the connection between 'development' and 'sustainability transitions': the rise of the so-called 'BRICS-plus' ${ }^{1}$ economies as most of the traditional Organization for Economic Co-operation and Development (OECD) economies plunged into a prolonged depressive malaise (Bogdan, Hurduzeu, Josan \& Vlasceanu, 2011; Pant, 2013; Van Agtmael, 2012), and the emergence of a global narrative that started with the 'green economy' discourse in 2009 (Death, 2014; Geels, 2013) followed soon after by the adoption of the Sustainable Development Goals (SDGs) in 2015. The primary implication

1 BRICS is an association of emerging/developing countries namely Brazil, Russia, India, China and South Africa. The BRICS-plus initiative is aimed at developing the outreach activities of the BRICS countries with the global South and building wider partnership with emerging markets and developing countries. 
of the convergence of these trends over nearly a decade is the need to rethink the relationship between development and sustainability transition. Although Scoones, Leach and Newell (2015) make a significant contribution in this regard the focus in this chapter is not on the development-sustainability nexus in general. Instead, the focus is more on sustainability transitions and 'developmental states' - the latter usually regarded as having a historic mission to accelerate the development and modernisation processes in the spirit of 'catch up' (Evans, 2010).

Building on earlier work with similar aims (see Swilling and Annecke, 2012, Chapter 5), this chapter argues that we need to draw on the well-established literature on the developmental state (DS) and sustainability transitions (ST) in order to better understand the challenge of combining development strategies and commitments to ecological sustainability that many states in Africa now face since the adoption of the SDGs. This synthesis, in turn, needs to be brought into conversation with the African literature on 'governance for development'.

Given the contested nature of the term 'development', it is necessary to declare a specific point of departure. For this purpose, I favour the following definition of development by Castells and Himanen:

Development ... is the self-defined social process by which humans enhance their well-being and assert their dignity while creating the structural conditions for the sustainability of the process of development itself. (Castells \& Himanen, 2014:29)

This definition is useful because wellbeing rather than gross domestic product (GDP) per capita is at the centre. Following Sen (1999), this definition of development is not derived from an abstract categorical imperative but from the everyday processes of 'self-definition' via dialogical engagement, which are of course context-specific. However, these acts of becoming are inseparable from the wider process of structural change to ensure the longer-term sustainability of development processes. But the former is not conditioned by the latter - instead, the latter is the emergent outcome of the continuous struggles over the terms of the development process itself. Of course, this is not how 'Development' (with a big ' $\mathrm{D}$ ') is usually officially defined in mainstream narratives (Nederveen-Pieterse, 2000). Nevertheless, this is, most certainly, 'development' (with a small 'd') as a process of mutual flourishing within communities of human and non-human beings. For some, this takes us into what is referred to in the Latin American literature as 'postdevelopment' (Escobar, 2015), while for others it implies 'degrowth' (D'Alisa, Demaria \& Kallis, 2015) or 'alternative development' (Nederveen-Pieterse, 2000). Either way, wellbeing and a relational perspective seem to be what is common across nearly all perspectives that break with 'Development' (big ' $\mathrm{D}$ '). 
Following this perspective, ${ }^{2}$ a 'just transition' can be defined as a set of complex highly contested socio-political processes that result in (i) significant improvements in wellbeing for all (including the eradication of poverty and reduced inequalities, in particular asset inequality); and (ii) decarbonisation, the simultaneous restoration of degraded ecosystems, and radical improvements in resource efficiency. Achieving both via a just transition would require - and result in - far-reaching structural transformations that are arguably implied by the commitments embedded within the SDGs. An exclusive focus on the former will leave planetary systems to collapse resulting in rising prices of increasingly scarce resources, starting with the most sensitive which is food, but also water, energy and other extracted materials. No matter how progressive the government of the day may be, in a highly unequal world, the poor will suffer the most and the rich will be able to buy up a shrinking pool of resources. Conversely, strategies that only focus on the ecological sustainability of the planetary systems will tend to neglect what is needed to build the capabilities of the poor to define their own solutions and the capabilities of the state to intervene where required. Where the fusion of these goals becomes most explicit is in the idea of a just transition expressed most concretely in the call for energy democracy as a way of reorienting the directionality of the global renewable energy revolution (Burke \& Stephens, 2018).

The problem, however, is that the literature on developmental states and sustainability transitions have evolved in parallel without much cross-over (for a key exception and seminal contribution see Johnstone and Newell, 2018). This is an opportune moment to synthesise this literature in order to conceptualise in a more detailed way the dimensions of a sustainability-oriented polity that holds in balance the developmental and sustainability agendas (in a way that avoids the usual 'trade-off' narrative introduced by the 'triple bottom line' approach).

While the DS literature has been widely used to address the development challenges of industrialising economies in the global South (Bagchi, 2000; Chang, 2007; Chibber, 2002; Edigheji, 2010; Evans, 2010; Jayasuriya, 2001; Kohli, 2006; Leftwich, 1995, 2000; Mkandawire, 2001; Noman, Botchwey, Stein \& Stiglitz, 2011; Rodrik, Subramanian \& Trebbi, 2004; Swilling, 2008; Swilling, Musango \& Wakeford, 2015; Thompson, n.d.), this literature has generally neglected to deal with environmental challenges in general and STs in particular. The ST literature generally has ignored development (with exceptions such as Scoones, Leach and Newell, 2015; Swilling and Annecke, 2012;), but there is an emerging literature

2 This definition fuses together various strands in development studies, including Sen's capability perspective, the writing on wellbeing, traditional concerns with structure in development economics, and ecological and institutional sustainability thinking. 
that has started to be used to address this lacuna, with a significant body of work already done on East Asian economies (Angel \& Rock, 2009; Berkhout, Angel \& Wieczorek, 2009; Rock, Murphy, Rasiah, Van Seters \& Managi, 2009) and now also starting to be applied in the South African context (Baker, 2015; Baker, Newell \& Philips, 2014; Lawhon \& Murphy, 2011; Swilling \& Annecke, 2012).

Scoones et al. (2015) have achieved a significant synthesis of the development economics and ST/transformation literature, with specific reference to the 'politics of green transformations'. In a subsequent publication, Johnstone and Newell (2018) build on this foundation and offer a perspective on sustainability transitions that draws on rich traditions in radical political economy. This chapter builds on these works, the ST literature on East Asia plus my previous work on synthesising development, institutional and ecological economics to theorise the 'greening' of the developmental; Swilling, Musango \& Wakeford, 2016). The resultant synthesis is then brought into conversation with the debates about the African developmental state, in particular, the contributions in a volume edited by Noman et al. (2011).

As already noted, the DS and ST literature agree on the need for deep structural transformation, but with two different ends in mind: for the DS literature, the end is accelerated economic 'Development' (big ' $\mathrm{D}$ ') that substantially raises the average GDP per capita with a focus on industrialisation and urbanisation; while for the ST literature the end is a socio-technical transition that results in a lowcarbon resource-efficient economy. Johnstone and Newell (referred to later) go a long way towards achieving such a synthesis, but like most work in the political economy field, they neglect the institutional context. I will argue that the synthesis of this literature needs, rather, to open up a space for a more detailed discussion about governance for a just transition, with special reference to how we deepen our understanding of the dynamics of the polity in African governance systems.

\section{Developmental states}

The defining feature of DSs is that they are primarily concerned with the structural transformation of modernising economies (Evans, 1995; Kohli, 2006; Noman et al., 2011). The legitimation of DSs is derived primarily from their ability to promote sustained growth and development via aggressive industrialisation (Chibber, 2002). In practice, the underlying economic rationale for DSs has been an acceptance that markets left to their own devices will tend towards disequilibrium in unequal developing economies and therefore state intervention is a necessity. However, at the ideological level, DSs were excellent at extolling the virtues of capitalism and even, when it suited them, the logics of neo-classical economics. As summarised by Khan (2008), they promoted sustained growth and development by deploying several unique abilities. These included the ability to extract and 
deploy capital productively, generate and implement national and sectoral plans and effect dynamic egalitarian and productivity-enhancing development programmes in land, education and training, small enterprise, infrastructure and housing sectors. In addition, DSs have been able to manipulate private access to scarce resources through, among others, financial sector re-engineering, subsidies, taxes, concessions and high levels of lending.

An authoritarian form of governance was often pursued by states that were determined to tightly manage and cultivate a state-dependent national business class. The cultivation of close and productive relationships with business on terms set by the political elite and enforced via state institutions was the norm. Interest groups were managed using corporatist arrangements, often in authoritarian topdown ways to impose the state's agenda versus the more consensual type of social corporatism that was pursued in South Africa after 1994. Thus the East Asian DS was characterised by a capacity to coordinate the efforts of individual businesses by encouraging the emergence and growth of private economic institutions, target specific industrial projects and sectors, resist political pressure from popular forces and, at times, also brutally suppress them. These DSs often mediated and/ or insulated domestic economies from (extensive) foreign capital penetration during the early stages and, most importantly, sustained and implemented a project of productivity improvement, technological upgrading and increased market share that broke them out of a path-dependent low-growth economic trajectory (Chang, 2007).

The institutionalisation of the polity of the developmental state has received much attention since the 1990s. In a seminal contribution, Leftwich (1995) summarised what many regard as the key institutional characteristics of the typical polity of the typical DS as follows:

a 'determined developmental elite' committed to the modernisation project;

'relative autonomy' from major capitalist economic interests who are always keen to capture the state;

'a powerful, competent and insulated economic bureaucracy' that enjoys the highest possible political support but operates without too much political interference;

a 'weak and subordinated civil society' which means there are no rival centres of alternative policy formation;

the 'effective management of non-state economic interests' via formal structured compacts, incentives and penalties; and

accessible and usable institutions of 'repression, legitimacy and performance'. 
What is distinctive about the literature on developmental statism in Africa is whether these characteristics - derived from the East Asian context - are applicable in the African context (Mkandawire, 2001), especially in light of the pervasiveness of neo-patrimonial modes of governance in post-independence Africa (Booth \& Golooba-Mutebi, 2012; Kelsall, 2013; Pitcher, Moran \& Johnston, 2009). Originating in Fanon's classic narrative on the weakness of the 'national bourgeoisie' in post-colonial Africa (Fanon, 1963), the core questions asked in this literature are about whether it really is possible to talk about a 'developmental elite' acting 'relatively autonomously' from capitalist interests by way of a 'competent bureaucracy' that 'effectively managed' developmental compacts with non-state actors. Or whether it is preferable to talk about 'developmental neo-patrimonialism'. But before addressing this African debate, the wider conceptual framework needs to be put in place.

Once East Asian DSs had consolidated an industrial base through technological capacity building, institutional functionality and human developmental capabilities, their focus shifted from the late 1990s onwards from massive investments in the material conditions of modernisation to establishing the conditions required by the emergent knowledge economy created by the information revolution (Evans, 2012). Three new tasks emerged with major implications for the structures and logics of the polities that drove the initial phases of development. Together, these three tasks clearly defined the slightly more consensual modes of governance that emerged during the transition from accelerated heavy industrialisation/ urbanisation to an emphasis on quality and greening - a process often associated with 'de-nationalisation' of the 'commanding heights' of the economy (except for the China case).

Firstly, if institutions are accepted as key to an environment that fosters innovation (following the logic of the new mainstream institutional economics - see Rodrik et al. 2004), then the main challenge becomes the building of networks and new value chains as the drivers of growth, the development of leadership capabilities to build effective institutions and, more importantly, the facilitation of networks of institutions that span multiple sectors of the economy. This new kind of political leadership has to strike a very delicate balance between regulation of shared norms/ values (e.g., a patriotic or nationalist commitment to national development) and self-managed implementation (especially important for fostering innovation). As will be argued, this depended on the political will to re-organise the various dimensions of the polity (including political re-alignments), and in some cases, this meant using repressive force.

Secondly, no one disputes that knowledge and innovation matter. However, these are emergent properties that stem from dense networks of people, working together across institutional boundaries within quite well-defined institutional 
eco-systems, unconstrained by outdated (usually hierarchically organised) norms or an atmosphere of fear and conformity (that often prevailed during the earlier years of 'forced march' industrialisation/urbanisation). The private sector always under-invests in human capital and innovation networks because the direct returns to the investor are impossible to predict. Without state-led investment in these sectors, facilitated by an appropriately configured socio-political regime via universities, NGOs and developmental partnerships/compacts, knowledgebased, innovation-led economic development in the era of the network society may be impossible (Castells \& Himanen, 2014; Mazzucato, 2011). Indeed, the key constituency that gets included in the broadening out of 'collibratory' governance to support innovation and experimentation are a wide range of knowledge workers - entrepreneurs, researchers, inventors, innovators, venture capitalists, impact investors, NGOs, consultants, and so on.

Thirdly, embeddedness for the twenty-first-century DS might mean building a polity that broadens out developmental partnering with networks of civil society formations and smaller entrepreneurs rather than focusing only on the investment strategies of large corporates (as was the case during the early years when the focus was on the construction of a heavy industrial base). This kind of broad more consensual mode of governance may be particularly appropriate where the national business class is strong. A weak national bourgeoisie has traditionally been a good reason for developmentally-oriented states to get involved during the early stages of economic development to weld together local business elites into effective drivers of national investment-led development. But in situations where the national bourgeoisie is fully consolidated, the state has more freedom to integrate a wider set of class alliances. This may entail a multiplicity of smallish interventions, rather than a few, massive, physical infrastructure investments that satisfy the need for capital deepening but do little to redefine the institutional context for the circulation of the benefits. This, however, is only possible if there is sufficient capacity to handle these transaction costs.

\section{Sustainability transitions}

The multi-level perspective (MLP) is the most influential approach in the ST literature. In summary, the MLP makes a distinction between landscape pressures, socio-technical regimes, and innovation niches (Grin, Rotmans \& Schot, 2010). Landscape pressures are longer-term transformative socio-structural conditions such as demographic change, climate change, digitalisation, rising levels of education over time, ageing, resource depletion and cultural change. Sociotechnical regimes are specific configurations of technologies, markets, regulations, institutions, human capabilities and routines that make it possible to reproduce societal systems such as energy provision, mobility, market-based property 
development, food systems, industrial agriculture, water provision and waste management. Regimes display a high degree of obduracy in the face of landscape pressures. Niche innovations emerge when networks of innovators (technological financial, institutional) respond to landscape pressures by collaborating to develop potentially new emergent socio-technical regimes (e.g., renewable energy, or organic food) that can either replace old regimes or get absorbed by those regimes that realise they need to adapt to landscape pressures.

Transition researchers characterise socio-technical regime change - or structural transformation - as being predicated on the ways in which shifting landscape pressures impinge on a regime and the extent to which responses to these pressures are coordinated, both from inside and outside the regime to accommodate or resist these pressures (Smith, Stirling \& Berkhout, 2005). In this way, the ST literature opens up the issue of governance interventions to facilitate regime transformation, but for some this has not hitherto been taken far enough (Geels, 2014; Hess, 2014; Johnstone \& Newell, 2018; Meadowcroft, 2011). It is not only the objective reality of these pressures that matters, but more importantly, the adaptive capacity, or the relationships, resources and their levels of coordination within the polity that shapes responses to these pressures. This can be the outcome of historical processes (e.g., a gradual shift in consumer choices or evolution of new technologies) or purposively informed by a strategically aligned polity with a shared vision and capacity to implement a coherent set of policies. The ST literature is critical of the neo-liberal assumptions about the virtues of the market, hence the constant insistence on a role for the state. As Johstone and Newell suggest:

In short, within sustainability transitions literatures 'the state' has been an assumed but underconceptualised, secondary aspect in explorations of socio-technical transitions and niche development. (Johnstone \& Newell, 2018:74)

Johnstone and Newell identify five implicit assumptions about the nature and role of the state in the ST literature (Johnstone \& Newell, 2018:74-76). Firstly, there is rising awareness of the key role of state institutions in accelerating transitions. The supportive role of state institutions in the rapid rise of renewable energy across all world regions is a case in point (Mazzucato, 2015). Secondly, there is growing recognition of the political role played by coalitions of incumbents that resist STs. They can use state institutions, and equally state institutions can be used against them. Thirdly, it is becoming increasingly clear that state institutions will be required to actively destabilise and discontinue unsustainable socio-technical regimes (e.g., oil-based motor vehicle engines) - they are unlikely to simply wither away in the face of landscape pressures and niche innovations. Fourthly, the rising number of case studies of STs reveals how significant each context is. Regimes, niches and transition pathways are profoundly embedded within - and shaped 
by - the dynamics of each specific context. How these dynamics pan out in South Africa will be very different in South Korea, or Europe, or Brazil. Fifthly, despite the foregoing four trends, when the state is discussed in the ST literature there is little recognition of its relational nature. Instead, ' $[\mathrm{s}]$ trict dividing lines often persist in relation to "state", "market" and "civil society", and as a result the "processual and dynamic nature of the state in configuring geometries of power between different actors ... remains largely unexplored' (Johnstone \& Newell, 2018:75).

\section{Rethinking governance}

Drawing from cutting-edge thinking in contemporary political economy, Johnstone and Newell proceed to suggest five particular 'dimensions of state power' (Johnstone \& Newell, 2018:75) that align closely with Jessop's strategicrelational approach. Firstly, the assemblages of state institutions evolved historically in ways that are specific to each regional and national context. This is why an understanding of the dynamics of STs cannot be simplistically derived from global dynamics. Contextual specificity matters. The role of the 'mineral-energycomplex' in the South African case is a case in point (Jaglin \& Dubresson, 2016). Secondly, the political economy of energy is such that there are global geo-strategic interdependencies that can enhance or constrain energy transitions at the national and local levels. For example, states use commercial and military means to secure and protect access to fossil fuel supplies in global markets in ways that can constrain the expansion of renewables at the national level. The former South African president's determination to procure a Russian nuclear power plant is a good example. But the drastic drop in prices of renewables in South Africa due to subsidies in other jurisdictions has the opposite effect. Thirdly, there are always multiple centres of power in any state system. This is why it is often meaningless to talk about 'the state' as if it exists in reality as a single unified entity. It can exist as an idea or political project, but in reality, it is an assemblage of diverse institutions. Fourthly, a relational approach to governance means accepting there are no neat dividing lines between polities and societies. State institutions reflect and refract particular sets of interests, sometimes in contradictory ways. This often renders references to 'the state' as distinct from 'the market' and 'civil society' somewhat meaningless. The dependence of economic growth on affordable energy supplies, for example, often gives large energy providers a privileged place in the polity which they use to protect their positions and systems. Again, this is reflected in the way the South Africa polity has worked. Fifthly, there is insufficient attention to the material implications of certain technologies in shaping institutional routines and practices that may influence the directionality of sustainability transitions' (Johnstone \& Newell, 2018:78, emphasis added). In short, as in the South Africa case, the dominance of the 'mineral-energy-complex' not only retards the 
diversification of the economy and reinforces social exclusion; it is also premised on the 'normalisation' of a particular set of technological practices that get inscribed into policies, laws and regulatory regimes that serve to (wittingly and unwittingly) exclude potentially more productive and inclusionary alternatives.

Whether or not the directionality of the transition to more sustainable modes of production and consumption (SDG 12) is oriented towards a just transition (SDGs 1 and 10) will depend on power dynamics within the polity. With Johnstone and Newell's framework in mind, according to Jessop, the polity is:

the institutional matrix that establishes a distinctive terrain, realm, domain, field, or region of specifically political actions. ... Further, while the polity offers a rather static, spatial referent, politics is inherently dynamic, openended, and heterogeneous. (Jessop, 2016:17)

Jessop's 'strategic-relational approach' is useful for understanding the contemporary state in both the developed and developing world contexts (Jessop, 2016). He argues that from the 1970s onwards there has been a gradual 'de-centering' of the polity as the state 'retreated' (to use the word Strange used in the 1990s (see Strange, 1996) as the primary driver of the policies that shape the future. The result is the emergence of a polity that is far more complex than what existed in the old state-centric polities. Polities have evolved into complex semi-institutionalised partner-based assemblages and dynamic sets of transactions. In the academic and policy literature, the notion of 'governance' emerged to capture this shift away from state-centric conceptions of the polity (Hajer, 2009; Jessop, 2003; Kooiman, 1993; Offe, 2009). Research agendas also moved away from a preoccupation with structures of government to the relational dynamics of governance. Out of these emerged what Schot and colleagues refer to as 'frame 3' policy-making: a multistakeholder, multi-goal process that requires a far more complex set of institutions and leadership skills (Schot \& Steinmuller, 2016). Governance, however, is less about the long-term directionality of the polity, and more about relational and dialogical management of complexity over the short term (Offe, 2009). It is, in short, the outcome of political weakening and has, unsurprisingly, generated a reaction. Jessop argues there is a counter-trend initiated by forward-looking political leaders with long-term visions who are interested in the 'governance of governance', which is what he refers to as 'collibration'. This consists of a new set of intermediary public institutions that have the capacity and mandate to set the terms of governance so that the directionality of the relational polity is determined politically rather than through a constellation of negotiated deals.

Jessop's notion of 'collibration' is useful because it addresses a dilemma at the centre of the African literature on developmental statism, namely the tension between complexity and directionality. For those committed to social democracy, socialism 
or inclusive development, a return to state-centric polities is essential for achieving this kind of long-term directionality (Mitchell \& Fazi, 2017; Zenawi, 2011). For former Ethiopian prime minister Meles Zenawi, contra neoliberal economics, the 'activist developmental state' must be autonomous - but necessarily democratic - in order to catalyse accelerated development (Zenawi, 2011). However, this assumes that complexity can be rolled back. Under conditions of increasing complexity in a globalised digitalised information-rich world, directionality is unlikely to be achieved by returning to state-centric polities. The alternative lies in Jessop's notion of 'collibration' - the emergence of a new generation of metagovernance institutions mandated to foster the 'governance of governance. The core skill required for this is process facilitation.

Drawing on a synthesis of Jessop's conceptions of the polity and Wilson's 'policy regime' theory, a more nuanced conception of the polity starts to emerge (Wilson, 2000). This is useful for making sense of the kinds of 'sustainability-oriented polities' that would be required in the African context to drive a just transition.

The polity can be understood as the space or arena that demarcates a specific constellation of political and quasi-political actors engaged in a defined set of contestations to influence policy outcomes and the actual roles of particular state apparatuses. This constellation of actors usually share a sufficient consensus about a set of ground rules for conducting the business of everyday politics within and outside the formal institutions of the state apparatus. These actors (interests) subscribe to certain underlying beliefs about the legitimacy of the system, how institutions are controlled in various ways, and the way cooperation and opposition work. They get organised into competing factions or alliances - and related policy networks - to secure advantages in the policy-making space and the wider polity. In other words, a polity goes beyond the governing elite and the state apparatuses that the DS literature has tended to focus on.

The nature and character of the polity demarcate the space within which the political game is conducted across various arenas (parliament, executive, media, civil society, judiciary, local/regional space-economies, organised business, policy networks, personal networks and business sectors). Within this space, all the key actors operate in ways that more or less reproduce the overall stability of the political system. Their differences are contestations over the direction of policy in ways that do not subvert the overall coherence of that political system. Some actors, however, operate within the polity on these terms, but also either directly or indirectly act via proxies outside and against the polity and the way it is configured. These political hybrids have demands that could be revolutionary in nature (i.e. replacement of the polity by a completely different configuration of political and institutional arrangements), or reformist (i.e. for the reconfiguration 
of one or more fundamental dimensions of the polity, such as, for example, reduced influence of big business or constitutional reform to reduce the powers of the head of state). This approach can help understand the dynamics of political instability in African polities. Without a sufficiently broad consensus across political elites that the polity is an appropriate space within which to engage in political competition, the result is episodic political instability. This has been a common phenomenon across different African regions.

Policy regime theory suggests that the polity has four dimensions (Wilson, 2000). The first of these is where power relations are played out and reproduced within the polity. This refers to how political power is constituted, distributed and maintained by the 'power elite' (Wright Mills, 1956). This applies in particular to the governing party and its allies within and outside government. Second, there is usually a shared underlying policy paradigm, in particular at the sectoral level (e.g., coal-based energy generation) but also at the macro-economic level (e.g., a belief in neoclassical approaches to fiscal discipline and monetary policy). A policy paradigm incorporates a specific set of beliefs/assumptions which, in turn, determines how policy problems are defined (e.g., a faith in markets, or a commitment to the SDGs). A shared policy paradigm is understood and narrated by the different policy actors who engage in the everyday business of politics, which is why a shared language emerges to enter into dialogue and negotiation.

Thirdly, there is the way government and state institutions are organised and legitimised. Although this reflects the underlying power relations and paradigm commitments, these power relations do not always determine how a government is organised. Organising principles get institutionalised and can have a relative autonomy and constitutional fixity that can be at odds at times with the underlying power dynamics. This happened in South Africa during Jacob Zuma's presidency (2011-2017) when the Constitution came to be regarded as an obstacle in the way of 'radical economic transformation'. Arguably this is also what is happening as the Trump presidency acts against a wide range of constitutional norms. Fourthly, there is the policy content of the policies themselves that are debated and adopted by policy actors within a given polity - this being the traditional focus of policy analysis.

This four-dimensional conception of the polity is useful for revealing how fundamental policy change (fourth dimension) cannot take place without changes in the three dimensions of the policy that the fourth depends on: if power relations and the policy paradigm do not change, how can we expect the real substance of policy content to change? 
The rise of governance since the 1970s is essentially about the organisation and outward expansion of the polity to incorporate policy actors that were previously excluded from having any influence on policy. Much of this was to compensate for the weakening of the state as complexities mounted. However, collibration is the counter-trend, referring to the way key actors within the polity seek - with varying degrees of success - to harness and mobilise governance and, indeed, complexity more generally. It is this kind of 'governance of governance' that has the potential to guide and shape long-term structural transformation.

The key contribution made by policy regime theory is that it helps explain policy 'lock in' by referring to the complex interaction between all four dimensions of the polity, without assuming a priori that any one dimension determines any of the others. Determination, after all, is context-specific. This goes way beyond the traditional purview of the policy analysis community which is essentially locked into dimension 4 (policy content) and to some extent dimension 3 (organisation of government). However, the experience of policymakers and a considerable body of research suggests that policies do in fact reflect underlying power dynamics (dimension 1) and paradigm commitments (dimension 2), and therefore unless these are changed, changes in dimensions 3 and 4 will be unlikely. Each context, however, will be different. In some instances, policy change (dimension 4) can drive changes in the other dimensions (especially policy shifts driven by global dynamics or local crises), while in other contexts nothing changes until the underlying power dynamics (dimension 1) change, or the policy paradigm shifts in response to cultural or knowledge-related trends (e.g., the impact of environmental thinking).

In reality, polities tend to change in response to 'stressors' and 'enablers' (Wilson, 2000), often represented by some kind of external shock to the system (e.g., an 'upset' election, corruption scandal, economic crash, violent conflict, assassination, re-alignment of political forces in the governing party, mass uprisings, constitutional crisis or warfare). Stressors can emerge when new power players emerge and/or external dynamics force policy changes. Examples of enablers would be a paradigm shift, such as the gradual realisation that climate change needs to be addressed in some way. As a consequence of a shock (or series of shocks) and the nature of the enablers and stressors, the dynamics and character of the polity will change through some contextually specific combination of power shifts (dimension 1), paradigm shifts (dimension 2), a legitimacy crisis (dimension 3), and organisational and policy change (dimension 4). A re-alignment of forces and dynamics within the polity can emerge from any one of these dimensions, although dimension 1 is where the most significant shifts will most often originate. 
As will be shown below, developmentally-oriented polities at the heart of DSs reflected the underlying constellation of forces (dimension 1) that were united behind a particular developmental paradigm (dimension 2). Government was re-organised from time to time (including successive phases of nationalisation and de-nationalisation of industries), and long-term policies were crafted and implemented by relatively strong bureaucratic elites. STs would require a similar alignment to sustain a long-term commitment to structural transformation via a just transition, but to date, there is no equivalent stable pattern for STs as in the case of the DSs. As will be shown, East Asian DSs were forced to adopt environmental policies (dimension 4) because of external pressures (environmental regulations adopted by trading partners) that caused a paradigm shift of sorts (dimension 2). The introduction of feed-in tariffs in Germany that triggered the renewable energy transition in that country was a policy change (dimension 4) (Debor, 2018), but reflected a deeper shift in power as the greens and the environmental movement got stronger (dimension 1) and an environmental paradigm shift took place that transcended party-political divisions (dimension 2).

\section{Structural transformation, just transitions and the shaping of the polity}

The purpose of the existing DSs was to drive the long-term structural transformation process of economic development (most commonly via industrialisation and urbanisation) in order to achieve a high level of human wellbeing with respect to income, education and health. Building on the ST literature, an ST can only be envisaged if a specific combination of state apparatuses facilitates a long-term structural transformation process that results in socio-technical transitions to more sustainable modes of production and consumption, with special reference to decarbonisation, resource efficiency and ecosystem restoration. When these two conceptual frameworks and associated goals are combined, it becomes possible to imagine a just transition.

A DS, however, is not merely defined by the goals it is committed to. The DS literature has paid considerable attention to the capacity of the state to instigate transformative developmental processes, paying special attention to the emergence of a (sufficiently uncorrupted) developmental bureaucracy and a well-entrenched policy management system. In short, this is about the way political leadership went about constructing and organising a developmentally-oriented polity and, in particular, quite an authoritarian mode of collibration. In many African countries, including South Africa, a developmentally-oriented form of collibration morphed into neo-patrimonialism (Chipkin \& Swilling, 2018; Khan, 2004; Pitcher et al., 2009). 
In contrast, the emphasis in the ST literature (and the transition management literature in particular) on collaborative stakeholder engagement reflects quite a sanguine view of governance. There is little appreciation of politics and practice collibration - the 'governance of governance' - as a specific responsibility of purpose-built state institutions mandated to set the goals and rules of the game for achieving long-term structural transformation via a just transition. Broadening out governance to improve stakeholder participation for its own sake ultimately makes little real difference other than creating an illusion of legitimation.

The ST literature on East Asia, is, however, somewhat different. Angel and Rock show how the considerable governance capacity of the East Asian DSs to drive development in ways that contradicted the neo-liberal script (because it was so interventionist) has become very useful for driving STs in response to environmental landscape pressures, in particular those globalisation dynamics that require East Asian economies to be 'greened' (Angel \& Rock, 2009; Rock et al., 2009). However, they correctly point out that landscape pressures, in general, are too diffuse and contradictory to be useful for isolating 'landscape variables in directing transition processes' (Rock et al., 2009:242). As a solution, they proffer the notion of a 'socio-political landscape' to refer to the 'institutions, values and regulations broadly guiding an economy' (Rock et al., 2009:242). This seems similar to the notion of the 'polity' as deployed in this chapter. However, given that the defining feature of landscape pressures is that they are long term and slowmoving, calling this a 'landscape' seems like a misnomer - the strategic coalitioning and political actions needed to guide structural transformation via a just transition are by no means slow-moving and are not nearly as long term as socio-technical landscape pressures like climate change, demographic change, resource depletion and values change. It, therefore, makes sense to retain the notion of the polity that recognises the highly contingent nature of power dynamics and political action.

The conception of the polity advocated in this chapter addresses the challenge faced by the ST literature to conceptualise the role of politics and state, and it goes beyond the narrow institutionalist perspective that tends to pervade most accounts of the DS in the DS literature. This analysis makes it possible to suggest that a just transition becomes a realistic outcome if a developmental sustainabilityoriented polity emerges. This would entail agreement within the polity that the overall goal of development is human wellbeing (income, education and health) within a sustainable world (decarbonisation, resource efficiency and ecosystem restoration). For this integrated goal to shape the direction of development, broader socio-technical and social-ecological landscape pressures would have to be seen by key actors within the polity as nudging historical processes in a way that reinforces the normative claims of these goal statements. Game-changing dynamics emerging 
from niche innovations and experiments should also be coalescing around viable future alternatives and coalescing into alternative socio-technical regimes (Avelino et al., 2014). However, the structural transformations needed for a just transition (at all four levels of transition) will only be achieved when there is a developmental sustainability-oriented polity led by a strategic coalition of interests that shares this paradigm, uses state institutions to drive a just transition and adopts an appropriate policy and legislative programme that is aligned with the overall goal.

\section{Sustainability-oriented development trajectories in Africa?}

The front page of an edition of The Economist magazine in 2000 depicted Africa as 'the hopeless continent'. In its 3 December 2011 edition just over a decade later Africa was depicted as 'the hopeful continent' and has since waxed lyrical about 'Africa Rising. For eight out of the ten years to 2011, economic growth rates in sub-Saharan Africa were higher than in East Asia, and six of the ten fastest-growing economies by 2015 were African. This kind of upbeat hype about African growth was also reflected in a spate of reports by leading consulting companies (Ernst \& Young, 2011; McKinsey Global Institute, 2010; Monitor, 2009) and financial institutions (International Monetary Fund [IMF], 2011; World Bank, 2011) that provided extensive data to back up their optimism.

However, at an African Union summit of Ministers of Finance and Economics in Abuja 27-31 March 2014, there were repeated warnings that this economic boom is too dependent on the extraction and export of primary resources. ${ }^{3}$ Primary resources still make up 86 percent of exports into non-African markets (United Nations Economic Commission for Africa [UNECA] \& African Union [AU], 2014:17). There seemed to be complete consensus at this summit that unless Africa implements what was repeatedly referred to as 'structural transformation', the economic fortunes of African economies will be determined by the notoriously unstable global commodity markets. Furthermore, extractive industries are seen to benefit only a narrow band of employees and shareholders with limited backward and forward linkages within the domestic economies.

The challenge, therefore, is how new political coalitions can emerge within African polities who realise the need to ensure that resource rents from the extractive sector are re-invested in the diversification of African economies to ensure sustained longterm economic growth. It is this process of change that is referred to in African discussions as 'structural transformation'. However, as Paul Collier has argued, the more dependent an economy becomes on the exploitation of natural endowments, the less incentive it has to diversify (Collier, 2010). This, in essence, is what the 'resource curse' is all about. Key consequences are state failure and resource

3 Personal observations by Mark Swilling, who attended the AU Summit. 
wars resulting from entrenched corporate and elite practices that prevent the re-investment of resource rents (Swilling, 2013).

No other region has had to face the challenge of development by paying attention to the resource requirements, carbon emissions and biodiversity impacts of development. Ignoring this challenge will mean that the African Union Vision 2063 will not be realised. More significantly, not tackling this challenge will mean ignoring the aspirations of Africa's youth majority, many of whom are now concentrated in Africa's cities which is where the third wave of African uprisings is taking place (Branch \& Mampilly, 2015). The first wave got rid of colonialism in the late 1950s/early 1960s; the second got rid of the dictatorships (and apartheid) in the 1980s/90s. In August 2016, 272 activists from the movements driving the third wave of uprisings met in Arusha, Tanzania, and issued the Kilimanjaro Declaration. One of the six 'declarations' were as follows:

Africa is a rich continent. That wealth belongs to all our People, not to a narrow political and economic elite. We need to fight for economic development that is just and embraces social inclusion and environmental care. We have a right to the 'better life' our governments have promised. (Africans Rising, 2016)

The United Nations Economic Commission for Africa, which has traditionally ignored the need to consider sustainability issues, completely changed its tune in its 2016 Report (UNECA, 2016), which built on the United Nations Conference on Trade and Development (UNCTAD) call for 'sustainable structural transformation' (UNCTAD, 2012). UNECA recognised in this report the significance of the adoption of the SDGs and the Paris Agreement on climate in 2015.

The starting point for UNECA is the argument it has mounted for many years now: 'high rates of growth over the past decade have not translated into the structural transformation of the economy. Manufacturing, also, has not made the expected contribution to aggregate output, trade or gross domestic product' (UNECA, 2016:53). Indeed, manufacturing now contributes less in percentage terms to GDP than it did 30 years ago! In its previous three reports, UNECA emphasised building state capabilities for fostering industrial policies, with a focus on commodities, trade and dynamic interventionist policy management. In its 2016 report, UNECA goes beyond this economistic focus and follows thinking that has emerged from the International Resource Panel (Swilling, 2016b) by recognising that 'decoupling of growth from resource use' (UNECA, 2016:59) provides a major opportunity for African economies to 'be among the leaders in designing the new global low-carbon economy' (UNECA, 2016:55). A three-pronged rationale for this conclusion is provided: decoupling will spur 'structural transformation' (echoing the UNCTAD report), 'increase knowledge intensity in production', and 'sustain global competitiveness' in a world committed to decarbonisation (UNECA, 2016:55). 
Significantly, by industrialisation UNECA does not simply mean manufacturing - instead it can be defined as 'promoting higher-productivity growth' across the whole economic system by making sure that governments develop 'capabilities to enable their enterprises to compete in global value chains, promote technical and economic innovation, develop new sectors (such as green industries), and diffuse new technologies (renewables, for example)' (UNECA, 2016:63). UNECA concluded that African governments 'need to understand how they can launch and sustain a holistic process of economic transformation, which greens the entire system, and drive the economy in a different manner from business as usual' (UNECA, 2016:65).

UNECA describes three strategies for achieving this, namely 'transitioning out of brown industries; greening existing industries by increasing resource productivity, cutting pollution, and managing chemicals more safely; and creating new green enterprises, such as producing green capital goods, generating renewable energy and providing environmental advisory services' (UNECA, 2016:69). Significantly, the UNECA report repeatedly emphasises that greening includes but is not limited to decarbonisation - it is, rather, primarily about resource productivity. This is why both are seen as sources of growth driven by innovation, a way of improving trade balances, fostering regional integration through cooperation to support innovation, stimulating resource efficiency, catalysing knowledge intensity, reducing pollution, and restoring ecosystems. Understood in this way, 'green industrialisation can contribute to faster, more equitable and more sustainable patterns of growth. This is a long-term commitment, and '[s]trategic vision and leadership at the highest level are thus critical to inclusive green industrialisation' (UNECA, 2016:70-71). These normative policy prescriptions are all well and good, but the UNECA document and similar perspectives lack an adequate theory of governance that takes politics, power and the limits of governance seriously enough.

\section{Rethinking governance for development in Africa}

The implications of the argument thus far for the African literature on developmental states and governance are as follows:

in the SDG era, the traditional debate about African developmental states must now engage the literature on sustainability transitions in order to conceptualise sustainability-oriented developmental states;

given increasing complexity in a globalised digitised world, the desire to rebuild state-centric polities ('developmental states') seems unlikely to succeed because it of necessity will entail the reduction rather than expansion of complexity; 
yet, at the same time, the need for purposive directionality to tackle the great African challenges of inequality and unsustainability has never been greater;

hence the usefulness of the notion of collibratory governance - it is a notion that makes it possible to reconcile the reality of increasing complexity and the normative strategic need for directionality;

collibratory governance in practice is about building a new generation of metagovernance institutions with a mandate and capabilities to facilitate new modes of partnering within reconfigured more inclusive polities;

polities, however, are not merely black boxes - analysis must address the four dimensions of the polity that interact in context-specific ways, namely power relations, paradigms, organisation/institutionalisation and policy content.

The African debates will be revisited from this perspective: how do we rethink African polities in light of the need to transition to sustainability-oriented developmental states with requisite capabilities for fostering sustainable infrastructure development?

The eloquent contributions to a remarkable online edited collection by the most respected analysts of African governance (Noman et al., 2011) provide a conceptually sophisticated and empirically-rich body of scholarship about the trajectories of African governance since decolonisation. The primary argument made in different ways across the chapters is that widespread adoption of neoliberal economic theory by Western governments, development aid institutions, development finance institutions and most economists (academics and consultancies) from the late 1970s onwards resulted in the introduction of a raft of governance reforms across Africa that failed empirically, not least because they were theoretically misguided. The alternative they collectively propose is what Khan refers to as 'growth-enhancing governance' (Khan, 2011).

In line with the DS literature already discussed, the overall consensus of the contributors the volume edited by Noman et al. (2011) is that economic growth is the ultimate end and that state-coordinated structural transformation is the means. Without in any way opposing the need for markets of all kinds, they disagree with the dominant view that minimising the role of the state will automatically result in market efficiencies in African economies. Their alternative is fairly obvious: because each context is unique, there cannot be a blueprint applicable to all contexts. Instead, institution-building in Africa must be about experimentation and incrementalism: experimentation to craft through trial-and-error what works in specific contexts, and to incrementally build institutions over time in accordance with actually existing capabilities rather than pursuing the delusions of 'big bangery' 
thinking. Concluding his critique of neo-liberal institutional monocropping and monotasking', Mkandawire writes:

One costly feature of the lost decades was the reduction in the space for experimentation within Africa and the one-size-fits-all institution-building tradition has produced a size that seems to fit no one. (Mkandawire, 2011:28)

Unfortunately, unlike the authors of the UNECA report referred to in the previous section, the contributors to the volume edited by Noman et al. (2011) do not refer to sustainability challenges. Economic growth is the overriding and exclusive goal. This is profoundly ironic: for a group that vehemently insists that context matters, it provides an analysis that ignores the profound contextual challenges and opportunities - arising from degraded soils, biodiversity loss, depleted water resources, resource inefficiencies and the extra-ordinary opportunities in Africa for leapfrogging over fossil-fuel-based energy systems (Africa Progress Panel [APP], 2015). Indeed, repairing the future may well be Africa's most significant business opportunity in the twenty-first century. It may also hold the key to escaping the resource curse. But for this to happen, African conceptions of context-specific governance must engage with the literature on sustainability transitions. Without this, strategically significant African positions like those articulated in the UNECA and APP reports, as well as alignment with the SDGs, will remain unsubstantiated by an appropriately rigorous re-conceptualisation of African developmental governance.

Following the logic of the argument thus far, this engagement must address three issues: what a sustainability-oriented developmental state means in the African context; why collibratory rather than state-centric governance makes sense; and how to rethink the form and content of African polities.

As the UNECA and APP reports acknowledge, Africa's opportunity to mount authentic context-specific development strategies occurs at precisely the historic moment when it is generally accepted that all future development has to occur within 'planetary boundaries' (Rockström et al., 2009). No other major world region has faced the development challenge within a carbon- and resource-constrained world. Ignoring this reality could result in the subversion of development strategies focused exclusively on growth. This can, however, be a major developmental opportunity if the transition to an ecologically more sustainable world is conceptualised as an intrinsic part of the overall commitment to inclusive development in Africa. For this purpose, the conceptual distinctions between landscape pressures, sociotechnical regimes and innovation niches offered by the ST literature can help orient the experimental and incrementalist institution-building modalities advocated by Noman et al. (2011). This is illustrated here by some brief examples. 
The continent-wide commitment to accelerated infrastructure investments will propel African economies into the twenty-first century. Infrastructures are longlasting and play a key role in conducting resource flows through modern socioeconomic systems (Hoornweg \& Freire, 2013; Swilling, Robinson, Marvin \& Hodson, 2013; World Business Council for Sustainable Development, 2014). As the APP report reveals, electrical generation capacity in sub-Saharan Africa is equal to what exists in Spain! If Africa energises using fossil fuels, none of the climate targets agreed in Paris will be achieved. The world has an interest in Africa energising using renewables. And renewables are now cheaper than fossil fuels and arguably more technologically robust in countries with weak national grids. In short, with climate change and associated global agreements as landscape pressures, African developmental states could target renewables as the primary energy regimes of African economies. This would open up a myriad of niche-level innovation opportunities. Indeed, for countries like South Africa with a manufacturing base, such a strategic decision could drive a massive manufacturing boom. There are many similar examples with respect, for example, to food systems and agroecological farming to restore the degraded soils, new modes of sustainable water governance appropriate for water constrained countries, and radically different approaches to urban planning aimed at limiting suburban sprawl and maximising the use of public transit (Swilling, 2016a; Swilling et al., 2016).

It is remarkable that while the contributors to the volume by Noman et al. (2011) continuously emphasise learning, context-specific institution-building, experimentation and incrementalism, they say virtually nothing about how this gets done in practice. Furthermore, they also emphasise the importance of collaboration between sectors and stakeholders, rather than assuming that for-profit private sector organisations are the only viable agents of change (see Zenawi's discussion of state-aided growth-oriented 'rent creation', Khan's discussion of state-supported emerging entrepreneurs and Zalk's conception of industrial policies (Khan, 2011; Zalk, 2011; Zenawi, 2011). Again, no reference is made to how these relationships are formed and sustained, or who does this work. This neglect of the how of governance is all-pervasive in the African literature on governance.

The argument between state-centric and minimal state positions suffers from a failure to distinguish between what Jessop calls the 'idea of the state' and the 'reality of the state' (Jessop, 2016). The 'idea of the state' is a legitimate political project, thus making it the subject of debates on the role 'it' plays vis-à-vis the market and civil society. However, 'the state' does not exist in reality. The 'reality of the state' is a ramshackle assemblage of a range of quite different institutions, from national government departments, to subnational governments, parastatals, development finance institutions, regulatory and enforcement agencies (like the police). To assume 
they all form part of a single unified 'it' that acts out in a specific way (as implied by phrases like 'role of the state' or even 'state intervention) is a complete misnomer. Furthermore, in reality there are no clear boundary lines between 'the state', the 'market' and 'civil society'. From the perspective of Jessop's 'strategic-relational approach', in reality, state institutions enrol a vast range of actors from within and outside the polity and, as such, cannot be assumed a priori to exist in a coherent form. They need to get built and specific people need to be the institution-builders.

State institutions are generally responsible for one or two of the five primary governance functions, namely policy formulation (departments, legislatures), regulation (departments, special purpose agencies), enforcement (police, tax authorities), implementation (departments, subnational governments) and evaluation (departments, legislatures, independent agencies). Collibratory governance is about recognising the need for a fourth function, namely facilitation. To reconcile directionality and complexity (especially if sustainability-oriented development becomes the goal) without returning to state-centric polities, it will be necessary to build a new set of institutions with facilitation capabilities. These become the institution-builders and maintainers. An excellent example is the Economic Development Partnership (EDP) in South Africa's Western Cape Province. Set up by government, the EDP comprises 25 professionals whose exclusive role is the facilitation of partnerships between, in the first instance, government departments across different spheres of government, and then also between government and non-state organisations in the private and non-profit sectors.

Finally, it is necessary to move away from a 'black box' approach to the African polity. Following the argument made earlier in this chapter, detailed granular analyses of the inner dynamics of the polity will be necessary. This will need to include, firstly, an understanding of the underlying power relations at the very heart of the polity (for a good example see Chipkin and Swilling, 2018). Without this, facilitated collibratory governance to widen stakeholder involvement in the polity will be impossible. Secondly, an understanding of the potential and limitations of the (sometimes even contradictory) paradigm(s) shared by key actors within the polity will be required. Without this, learning and innovation will be difficult to achieve. Thirdly, how state/government institutions are organised, funded and operated will be necessary. This is where 'lock-in' and path dependency sets in, often conditioning constrained parameters within which policy alternatives are considered. Effective collibratory governance may entail reconfiguring and reassembling these institutions. Finally, if policy formulation includes taking into account all four dimensions of the polity, the chances are much greater that viable and implementable policies will be adopted. 


\section{Conclusions}

This chapter addressed the question of how best to understand the relationship between developmental processes and STs in Africa, with special reference to the political dynamics of developmental states. This has become an especially important challenge in light of resource-induced economic growth in many African economies. These countries want to implement a twentieth-century conception of accelerated development inspired by the East Asian industrialisers, but now in a climate- and resource-constrained world. Most important of all, after the publication of the UN SDGs in August 2015, the global discourse is shifting from the old 'MDGs-plus-green economy' framework to the globally approved SDG framework that firmly and irrevocably inserts the 'people-planet-prosperity-peacepartnership' paradigm into official definitions of sustainable development at global and national levels.

Both the DS and ST literature acknowledge that structural transformation is needed, but each with respect to the hitherto separated goals of human wellbeing (and more narrowly economic development) and sustainability (and more narrowly environmental improvements). Building on the emerging literature on East Asia and South Africa that attempts to fuse these separate research trajectories, it was argued that an integrated conception of structural transformation will be needed that is driven by a commitment to both the goals of human wellbeing and sustainability. However, the expected just transition this could give rise to will not happen simply because there is a shared normative commitment, as is now reflected in the adoption of the SDGs. Nor will much progress be made by formulating bland managerialist policy prescriptions that ignore underlying power dynamics and paradigm differences. An adequate fusion of the core body of concepts in the DS and ST literature will need to make space for an understanding of the political dynamics of the polity. The polity is a space of policy-related action and engagement by a wide range of actors within and outside the formal political system that operates in four dimensions: power dynamics, paradigm commitments, state organisation and policy programmes. The sustainability-oriented effects (and their counter-vailing tendencies) at landscape, regime and niche levels are played out within the polity, resulting in changes over time in power dynamics, paradigms shifts, state organisation adaptations and the adoption of new policies.

In light of the adoption of the SDGs and the circulation of the UNECA and APP reports, it will be necessary to conduct many more case studies in the African context where developmental and sustainability goals need to be reconciled in order to achieve the just transition envisaged by these initiatives. This chapter has contributed an approach that could guide this kind of future research. 


\section{References}

Africa Progress Panel. (2015). Power people planet: Seizing Africa's energy and climate opportunities. Geneva: APP.

Africans Rising. (2016). The Kilimanjaro Declaration, Arusha, Tanzania, 23-24 August. https://www.africans-rising.org/ the-kilimanjaro-declaration/ [Accessed 30 September 2019].

Angel, D. \& Rock, M.T. (2009). Environmental rationalities and the development state in East Asia: Prospects for a sustainability transition. Technological Forecasting and Social Change 76(2): 229-240. https://doi. org/10.1016/j.techfore.2008.01.004

Avelino, F., Wittmayer, J.M., O’Riordan, A., Haxeltine, A., Weaver, P. et al. (2014). Game-changers and transformative social innovation: The case of the economic crisis and the new economy. TRANSIT working paper 1, TRANSIT: EU SSH 2013.3.2-1 Grant agreement no. 613169, Rotterdam: DRIFT.

Bagchi, A.K. (2000). The past and the future of the developmental state. Journal of WorldSystems Research 1(2): 398-442. https:// doi.org/10.5195/JWSR.2000.216

Baker, L. (2015). The evolving role of finance in South Africa's renewable energy sector. GeoForum, 64: 146-156. https://doi. org/10.1016/j.geoforum.2015.06.017

Baker, L., Newell, P. \& Philips, J. (2014). The political economy of energy transitions: The case of South Africa. New Political Economy 19(6): 791-818. https://doi.org/ 10.1080/13563467.2013.849674

Berkhout, F., Angel, D. \& Wieczorek, A.J. (2009). Asian development pathways and sustainable socio-technical regimes. Technological Forecasting and Social Change 76(2): 218-228. https://doi.org/10.1016/j. techfore.2008.03.017

Bogdan, L., Hurduzeu, G., Josan, A. \& Vlasceanu, G. (2011). The rise of BRIC, the 21 st century geopolitics and the future of the consumer society. Romanian Review on Political Geography / Revista Romana de Geografie Politica 13(1): 48-62.
Booth, D. \& Golooba-Mutebi, F. (2012). Developmental patrimonialism? The case of Rwanda. African Affairs 111(444): 379-403. https://doi.org/10.1093/afraf/ ads026

Branch, A. \& Mampilly, Z. (2015). African uprising: Popular protest and political change. London: Zed.

Burke, M.J. \& Stephens, J.C. (2018). Political power and renewable energy futures: a critical review. Energy Research and Social Science 35: 78-93. https://doi. org/10.1016/j.erss.2017.10.018

Castells, M. \& Himanen, P. (2014). Reconceptualizing development in the global information age. Oxford: Oxford University Press. https://doi.org/10.1093/acprof:o so/9780198716082.001.0001

Chang, H.J. (2007). Bad Samaritans: Rich nations, poor policies and the threat to the developing world. London: Random House.

Chibber, V. (2002). Bureaucratic rationality and the developmental state. American Journal of Sociology 107(4): 951-989. https://doi.org/10.1086/341010

Chipkin, I. \& Swilling, M. (2018). Shadow state: The politics of betrayal. Johannesburg: Wits University Press. https://doi. org/10.18772/22018062125

Collier, P. (2010). The political economy of natural resources. Social Research 77(4): 1105-1132.

D’Alisa, G., Demaria, F. \& Kallis, G. (2015). Degrowth: A vocabulary for a new era. New York: Routledge. https://doi. org/10.4324/9780203796146

Death, C. (2014). The green economy in South Africa: global discourses and local politics. Politikon, 41(1): 1-22. https://doi.org/ 10.1080/02589346.2014.885668

Debor, S. (2018). Multiplying mighty Davids? The influence of energy cooperatives on Germany's energy transition. New York: Springer. https://doi.org/10.1007/978-3319-77628-6 
Edigheji, O. (Ed.). (2010). Constructing a democratic developmental state in South Africa: Potentials and challenges. Cape Town: HSRC Press.Ernst \& Young. (2011). It's time for Africa: Ernst \& Young's 2011 Africa attractivness survey. London: Ernst \& Young.

Escobar, A. (2015). Degrowth, postdevelopment, and transitions: A preliminary conversation. Sustainability Science 10(3): 451-462. https://doi. org/10.1007/s11625-015-0297-5

Evans, P. (1995). Embedded autonomy: States and industrial transformation. Princeton, NJ: Princeton University Press. https://doi. org/ $10.1515 / 9781400821723$

Evans, P. (2010). Constructing the 21 st century developmental state: Potentialities and pitfalls. In: O. Edighej (Ed.), Constructing a democratic developmental state in South Africa: Potentials and challenges. Cape Town: HSRC Press.

Evans, P. (2012). What will the 21 st century developmental state look like? Implications of contemporary development theory for the state's role. In: W-k Chiu \& S-l Wong, Repositioning the Hong Kong government: Social foundations and political challenges. Hong Kong: Hong Kong University Press. https://doi.org/10.5790/ hongkong/9789888083497.003.0002

Fanon, F. (1963). The wretched of the earth. New York: Presence Africaine.

Geels, F. (2013). The impact of the financialeconomic crisis on sustainability transitions: Financial investment, governance and public discourse. Environmental Innovation and Societal Transitions 6: 67-95. https://doi. org/10.1016/j.eist.2012.11.004

Geels, F. (2014). Regime resistance against lowcarbon transitions: Introducing politics into the multi-level perspective. Theory, Culture and Society 31(5): 21-40. https://doi. org/10.1177/0263276414531627

Grin, J., Rotmans, J. \& Schot. (2010). Transitions to sustainable development: New directions in the study of long term transformative change.

New York: Routledge. https://doi. org/10.4324/9780203856598

Hajer, M. (2009). Authoritative governance. Oxford: Oxford University Press. https://doi.org/10.1093/acprof:o so/9780199281671.001.0001

Hess, D. (2014). Sustainability transitions: A political coalition perspective. Research Policy 43(2): 278-283. https://doi. org/10.1016/j.respol.2013.10.008

Hoornweg, D. \& Freire, M. (2013). Building sustainability in an urbanizing world. Washington, DC: World Bank.

International Monetary Fund. (2011). World economic and financial surveys: Regional economic outlook: Sub-Saharan Africa. Washington, DC: International Monetary Fund.

Jaglin, S. \& Dubresson, A. (2016). Eskom: Electricity and technopolitics in South Africa. Cape Town: University of Cape Town Press.

Jayasuriya, K. (2001). Globalization and the changing architecture of the state: The regulatory state and the politics of negative co-ordination. Journal of European Public Policy 8(1): 101-123. https://doi. org/10.1080/1350176001001859

Jessop, B. (2003). The governance of complexity and the complexity of governance: Preliminary remarks on some problems and limits of economic guidance. Lancaster, UK: Department of Sociology, Lancaster University. https://bit.ly/2VCyH1c [Accessed 16 September 2019].

Jessop, B. (2016). The state: Past present future. Cambridge: Polity Press.

Johnstone, P. \& Newell, P. (2018). Sustainability transitions and the state. Environmental Innovation and Societal Transitions 27 (June): 72-82. https://doi. org/10.1016/j.eist.2017.10.006

Kelsall, T. (2013). Business, politics and the state in Africa. London: Zed Press. 
Khan, F. (2008). Political economy of housing policy in South Africa 1994-2004. Stellenbosch, South Africa: Stellenbosch University.

Khan, M. (2004). State failure in developing countries and institutional reform strategies. In: B. Tungodden, N. Stern \& I. Kolstad (Eds), Toward pro-poor policies: Aid, institutions and globalization. Washington, DC: World Bank/Oxford University Press.

Khan, M. (2011). Governance and growth: History, ideology, and methods of proof. In: A. Noman, K. Botchwey, H. Stein \& J. Stiglitz (Eds), Good growth and governance in Africa: Rethinking development strategies. Oxford: Oxford University Press Scholarship. https://doi.org/10.1093/acprof:o so/9780199698561.003.0002

Kohli, A. (2006). State and development. In: D.A. Clark (Ed.), The Elgar companion to development studies. Princeton, NJ: Edward Elgar.

Kooiman, J. (1993). Modern governance: New government-society interactions. London: Sage.

Lawhon, M. \& Murphy, J.T. (2011). Sociotechnical regimes and sustainability transitions: Insights from political ecology. Progress in Human Geography 36(3):354-378. https://doi. org/10.1177/0309132511427960

Leftwich, A. (1995). Bringing politics back in: Towards a model of the developmental state. The Journal of Development Studies 31(3): 400-427. https://doi. org/10.1080/00220389508422370

Leftwich, A. (2000). States of development: On the primacy of politics in development. Cambridge, UK: Polity Press.

Mazzucato, M. (2011). The entrepreneurial state. London: Demos.

Mazzucato, M. (2015). The green entrepreneurial state. In: I. Scoones, M. Leach \& P. Newell (Eds), The politics of green transformations. London and New York: Routledge Earthscan. https:// doi.org/10.3898/136266211798411183

McKinsey Global Institute (2010). Lions on the move: The progress and potential of African economies. https://mck.co/2qGbXhZ [Accessed 15 September 2019].

Meadowcroft, J. (2011). Engaging with the politics of sustainability transitions,' Environmental Innovation and Societal Transitions 1(1): 70-75. https://doi. org/10.1016/j.eist.2011.02.003

Mitchell, W. \& Fazi, T. (2017). Reclaiming the state: A progressive vision of sovereignty for a post-neoliberal world. London: Pluto Press. https://doi.org/10.2307/j.ctt1v2xvvp

Mkandawire, T. (2001). Thinking about developmental states in Africa. Cambridge Journal of Economics 25(3): 289-313. https://doi.org/10.1093/cje/25.3.289

Mkandawire, T. (2011). Institutional monocropping and monotasking in Africa. In: A. Noman, K. Botchwey, H. Stein \& J. Stiglitz (Eds), Good growth and governance in Africa: Rethinking development strategies. Oxford: Oxford University Press Scholarship. https://doi.org/10.1093/acprof:o so/9780199698561.003.0003

Monitor (2009). Africa: From the bottom up: Cities, economic growth, and prosperity in sub-Saharan Africa. Houghton, South Africa: Monitor Group.

Nederveen-Pieterse, J. (2000). After post-development. Third World Quarterly 21(2): 175-191. https://doi. org/10.1080/01436590050004300

Noman, A., Botchwey, K., Stein, H. \& Stiglitz, J. (Eds). (2011). Good growth and governance in Africa: Rethinking development strategies. Oxford: Oxford University Press Scholarship. https://doi.org/10.1093/acprof:o so/9780199698561.001.0001 
Offe, C. (2009). Governance: An 'empty signifier'? Constellations 16(4): 551-562. https://doi.org/10.1111/j.14678675.2009.00570.x

Pant, H.V. (2013). The BRICS fallacy. Washington 2uarterly 36(3): 91-105. https://doi.org/10.1080/016366 0X.2013.825552

Pitcher, A., Moran, M.H. \& Johnston, M. (2009). Rethinking patrimonialism and neopatrimonialism in Africa. African Studies Review 52(1): 125-156. https:// doi.org/10.1353/arw.0.0163

Rock, M., Murphy, J.T., Rasiah, R., van Seters, P. \& Managi, S. (2009). A hard slog, not a leap frog: Globalization and sustainability transitions in developing Asia. Technological Forecasting and Social Change 76(2): 241-254. https://doi.org/10.1016 /j.techfore.2007.11.014

Rockström, J., Steffen, W., Noone, K., Persson, Å., Chapin, F.S. et al. (2009). Planetary boundaries: Exploring the safe operating space for humanity. Ecology and Society 14(2): Art. 32.

Rodrik, D., Subramanian, A. \& Trebbi, F. (2004). Institutions rule: The primacy of Institutions over geography and integration in economic development. Journal of Economic Growth 9(2): 131-165. https://doi.org/10.1023/ B:JOEG.0000031425.72248.85

Schot, J. \& Steinmuller, W. (2016). Framing innovation policy for transformative change: Innovation policy 3.0. Sussex, UK: University of Sussex, Science Policy Research Unit (SPRU).

Scoones, I., Leach, M. \& Newell, P. (2015). The politics of green transformations. London: Routledge Earthscan. https://doi. org/10.4324/9781315747378

Sen, A. (1999). Development as freedom. New York: Knopf.

Smith, A., Stirling, A. \& Berkhout, F. (2005). The governance of sustainable socio-technical transitions. Research Policy 34(10): 1491-1510. https://doi. org/10.1016/j.respol.2005.07.005
Strange, S. (1996). The retreat of the state. Cambridge: Cambridge University Press. https://doi.org/10.1017/ CBO9780511559143

Swilling, M. (2008). Tracking South Africa's elusive developmental state. Administratio Publico 16(1): 1-29.

Swilling, M. (2013). Beyond the resource curse: From resource wars to sustainable resource management in Africa. In: G. Minderman, V. Raman \& F. Cloete (Eds), Good, bad and next in public governance. The Hague: Eleven International Publishing.

Swilling, M. (2016a). Africa's game changers and the catalysts of social and system innovation. Ecology and Society 21(1): 1-37. https://doi.org/10.5751/ES-08226210137

Swilling, M. (2016b). Preparing for global transition: Implications of the work of the international resource panel. In: H.G. Brauch, U.O Spring \& J. Scheffran (Eds), Handbook on sustainability transition and sustainable peace. London: Springer. https://doi.org/10.1007/978-3-31943884-9_17

Swilling, M. \& Annecke, E. (2012). Just transitions: Explorations of sustainability in an unfair world. Tokyo: United Nations University Press.

Swilling, M., Musango, J. \& Wakeford, J. (2015). Developmental states and sustainability transitions: Prospects of a just transition in South Africa. Journal of Environmental Policy and Planning 5(5): 1-23. https://doi.org/10.1080/152390 8X.2015.1107716

Swilling, M., Musango, J. \& Wakeford, J. (2016). Greening the South African economy. Cape Town: Juta.

Swilling, M., Robinson, B., Marvin, S. \& Hodson, M. (2013). City-Level decoupling: Urban resource flows and the governance of infrastructure transitions. https://bit.ly/2ONgahr [Accessed 18 September 2019]. 
Thompson, G.F. (2003). Wither the 'Washington consensus', the 'developmental state' and the 'Seattle protests': Can 'managed free trade and investment' become an alternative development model? Problemas del Desarrollo 34(131): 219-238.

United Nations Conference on Trade and Development. (2012). Economic development in Africa report 2012: Structural transformation, decoupling and sustainable development in Africa. Geneva: UNCTAD. https://doi.org/10.18356/ eaf6f03c-en

United Nations Economic Commission for Africa \& African Union. (2014). Dynamic industrial policy in Africa. Addis Ababa: UNECA.

United Nations Economic Commission for Africa. (2016). Greening Africa's industrialization: Economic report on Africa. Dar es Salaam: UNECA.

van Agtmael, A. (2012). Think again: The BRICS. https://bit.ly/2BbtjZj [Accessed 18 September 2019].

Wilson, C.A. (2000). Policy regimes and policy change. Journal of Public Policy 20(3): 247-274. https://doi.org/10.1017/ S0143814X00000842
World Bank. (2011). Africa's future and the World Bank's support to it. Washington, DC: World Bank.

World Business Council for Sustainable Development. (2014). The urban infrastructure initiative. Geneva: World Business Council for Sustainable Development.

Wright Mills, C. (1956). The power elite. Oxford: Oxford University Press. https://doi.org/10.2307/1983710

Zalk, N. (2011). South African post-apartheid policies towards industrialization: Tentative implications for other African countries. In: A. Noman, K. Botchwey, H. Stein \& J. Stiglitz (Eds), Good growth and governance in Africa: Rethinking development strategies. Oxford: Oxford University Press Scholarship. https://doi.org/10.1093/acprof:o so/9780199698561.003.0012

Zenawi, M. (2011). States and markets: Neoliberal limitations and the case for the developmental state. In: A. Noman, K. Botchwey, H. Stein \& J. Stiglitz (Eds), Good growth and governance in Africa: Rethinking development strategies. Oxford: Oxford University Press Scholarship. https://doi.org/10.1093/acprof:o so/9780199698561.003.0005 